\title{
A Review of 'Organic Struggle: The Movement for Sustainable Agriculture in the United States'
}

Published: 31 May 2016

Keywords: big organic; local food systems; organic certification; organic farming; organic food economics

Organic Struggle: The Movement for Sustainable Agriculture in the United States

Obach BK

MIT Press: Cambridge, MA, USA. 2015

327 pp.; ISBN: 978-0-262-02909-4

Organic Struggle chronicles the challenges encountered by innovators in a growing segment of the U.S. food production and marketing system. Practiced for millenia by farmers before the introduction of chemical fertilizers and pesticides, and first developed more formally in Europe, organic farming practices began to gain prominence in the U.S. only in the 1950s. Far more than a system for producing food, this strategy has become a focus for those supporting healthy and pesticide-free products, for some who embrace the organic system as a food movement, and by many who disagree with the current domination of the country's food industry by large farms and a small number of multinational corporations. Within the organic sector there is debate between those who favor a system primarily run by local farmers who sell through small markets and CSAs, and others who insist that the 'Big-Organic' segment that now sells more than half of all organic food is doing more to help the environment in the large picture. Author Brian Obach describes this ongoing struggle.

Modern origins of formalized organic agriculture are thoughtfully traced to systems developed in northern Europe, especially in German-speaking Austria, Switzerland and Germany in the first half of the last century. Among the foundations for this movement are key research publications from Albert Howard based on experiences in India, the widely-cited lectures of Rudolph Steiner on biodynamic farming methods, and the reports of the Soil Association in
England. Notably missing from the chapter on early work in Europe is the excellent recent review Organic Farming: an International History by William Lockeretz [1]. Connections with religious beliefs and spirituality were seen as detrimental to acceptance of organic farming methods by some in the research establishment.

Popularizing organic farming in the U.S. is credited to J.I. Rodale and his son Robert Rodale, with the publication Organic Farming and Gardening [2] by Rodale Press and pragmatic research and demonstrations at the research center in Pennsylvania. Publication of Silent Spring by Rachel Carson [3] provided further impetus to this movement, one that became associated with innovative restaurants, farmers markets, and a diverse array of direct purchasing arrangements between farmers and consumers. A part of the 'struggle' is still associated with social justice, concerns about poverty, and preserving small farms.

Growing concern about the veracity of advertising of organic products in the marketplace led to calls for government certification of the production process. As described in Chapter 3, early statewide organizations in Maine and California in the early 1970s set the stage for wider conversations, and formation of the International Federation of Organic Agriculture Movements (IFOAM) in 1972 provided a global platform for discussion and an attempt at uniform standards. There were some cases of reported fraud in the system, along with several food scares in the 1980s that promoted action by the government. After protracted negotiation, a national organic standard was authorized in 1990 by the U.S. Congress, but it would be more than a decade before agreement was reached on the National Organic Program (NOP) that was enacted into law in 2002.

Moving back to the process, a continuing struggle between 'Big Organic' and various coalitions of small farm groups is described as the various factions debated the standards to be adopted, materials to be accepted in or- 
ganic farming, and the importance of independent oversight of the certification process. The two sides appear to have coalesced around the Organic Trade Association (OTA), representing big business, and the Organic Consumers Association (OCA) and Cornucopia Institute representing small farmers and concerned consumers. This oversimplifies the organizational landscape of organic groups, and Chapter 4 provides a more in-depth look at the genesis of several groups and the ongoing debates. The next chapter provides additional discussion of the criticisms of organic certification rules as well as concerns about health, continuing threats to the integrity of the original program, and the ever-present pressure of large industry to relax the standards to help them gain access to the continually growing market demand for organic food.

Treatment of labor, food justice, and distribution of benefits in the organic food system are explored in Chapter 6 . There is widespread concern that this niche food product has become available only to the elite, with prices often above those of conventional food in the marketplace. There is an emergence of competing groups, such as Certified Natural Growers (CNG) that uses a network of farmers who certify each other to avoid the federal bureaucracy and rigidity of the current NOP and independent certification system. A number of strategic initiatives from farmers and smaller states have expanded the options for farmers as well as consumers, and the overall effort is to create credibility in the way that food is produced and advertised.

A concluding chapter convinces the reader that the dynamic process of organic certification is still a work in

\section{References}

[1] Lockeretz W. Organic Farming: An International History. Oxfordshire, UK: CAB International; 2007. progress, with competing certifiers and divergent philosophies. An aspect not addressed in enough detail is the importance of organic exports from this country and especially imports from other places where certification may be in place but at times suspect in terms of the rigor of reviewing the production process and use of questionable inputs. Most certification organizations, public or private in the U.S. provide opportunity for farmers to certify for markets outside the U.S., particularly those in E.U., Japan, and Canada. This is a dynamic industry where there is remarkable room for innovation, and a segment of the food industry that continues to grow in response to consumer demand.

In conclusion, Organic Struggle is a book well worth reading to be able to grasp an overview of a complicated part of our contemporary food system. With ongoing debates, competing organizations, and a skeptical public that tries to understand this complex food landscape when making purchasing decisions, the book provides factual information and many quotes from farmers and other participants that delivers a rich resource to help the reader understand the organic farming and food system.

\section{Charles Francis}

Department of Agronomy \& Horticulture, University of Nebraska - Lincoln, Lincoln, NE, USA; and Plant Sciences Department, Norwegian University of Life Sciences, Ås, Norway; E-Mail: charf@nmbu.no

[2] Rodale JI, Rodale R. Organic Farming and Gardening. Emmaus, PA, USA: Rodale Press; 1942.

[3] Carson R. Silent Spring. New York, NY, USA: Ballantine Books, Random House Publishers; 2002. 